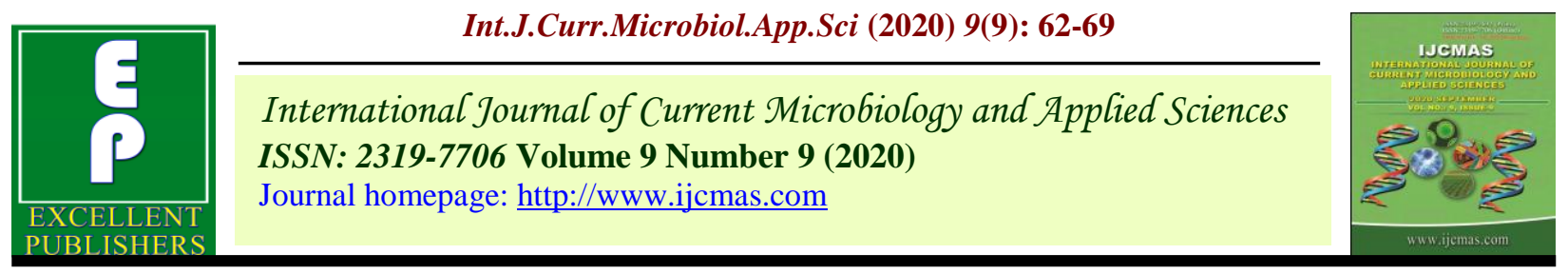

Original Research Article

https://doi.org/10.20546/ijcmas.2020.909.007

\title{
Studies on Linear Body Measurements of Red Kandhari Bullocks in their Breeding Tract of Maharashtra
}

\author{
D. V. Bainwad*, B. M. Thombre and G. K. Londhe \\ Department of Animal Husbandry and Dairy Science, Vasantrao Naik Marathwada Krishi \\ Vidyapeeth, College of Agriculture, Parbhani- 431 402, India \\ *Corresponding author
}

\begin{abstract}
A B S T R A C T
Keywords

Body

measurements,

Judging, Skeletal

growth, Live

weight, Vital organs

Article Info

Accepted:

04 August 2020

Available Online:

10 September 2020

Red Kandhari is one of the important breed of Marathwada region of Maharashtra State. The body measurements and body weight of Red Kandhari bullocks at more than 36 month of age were studied at different locations in the breeding tract. The body measurements play an important role in judging bullocks and often help in predicting probable value of the animals. The chest girth, body length and height are indicative of development of various body cavities, thus giving sufficient idea about development of vital organs. The body measurements indicate the skeletal growth of the animals. Body length and height at withers are the measures of bone growth while chest girth is a measure of development of muscles, bones and fat and it has close relationship with the live weight.

\section{Introduction}

Indian cattle population is an integral part of the agriculture. Thus the cattle occupy central position and are basis of the Indian rural livelihood security. The cattle biodiversity in India constitutes 40 well defined breeds of cattle, 13 breeds of buffaloes, 26 breeds of goat and 42 breeds of sheep (NBAGR, 2017). Red Kandhari is one of the important breed of Marathwada region of Maharashtra State. The Red Kandhari germplasm has very old and rich historical background. It is said that the breeding of cattle was taken up by the Royal

dynasty of king Somadeorai as far back as fourth century A. D. The cattle breed having red colour naturally acquires the name as Red Kandhari as it is sure that the breed would have been named by Raja Somadeorai in memory of his father as Raja Kanhar now misnomered as Red Kandhari (Chauhan et al., 2008). The overall performance of animals depends on morphometric, productive and reproductive characteristics, which play an important role for evaluation of animal. The Red Kandhari breed is reared mainly for draught purpose. Animals are medium in size, strong, compact and good looking. Body
\end{abstract}


colour is dull red to almost dark brown. Cows are low milk producers and bullocks of the breed are preferred over the Deoni breed for better draught ability and smaller size (Pundir and Singh, 2008). Therefore, the present study has been conducted to study body measurements, body weight at different age groups and the block effect on various characteristics.

\section{Materials and Methods}

\section{Selection of animals}

The data on body measurements of 851 Red Kandhari bullocks respective of sex was collected by taking actual measurements of each individual in different villages as mentioned in Table 1. From each tehsils on an average 94 bullocks / individuals at more than 36 months of age of Red Kandhari bullocks were chosen randomly for present study.

\section{Tools and Techniques of data collection}

The basic instrument for the present study was measuring tape and visual examination. The data was collected by measuring different body part and also by the visual examination. Efforts were made to avoid mechanical error, while recording the measurements. Arrangement was made to stand the animal on even surface and in normal position at the time of recording body measurement. The body measurements were measured with the help of standard metallic tape. The body measurement was recorded in centimetre. The data on morphometric characteristics of Red Kandhari bullocks were collected by actual measurements and interview with the livestock owners with the help of questionnaire.

The collected data of 851 Red Kandhari bullocks on body measurements and body weights were subjected to the Least Squares Analysis Technique as outlined by Harvey
(1990). The body weights at various age groups in Red Kandhari bullocks were estimated by using Agarwal's formula as outlined below.

Length x Chest Girth

Live body weight (in pound) =

$$
\text { Y }
$$

Where,

$Y=9.0$ if girth is less than 1.62 meters

$Y=8.5$ if girth is between 1.62-2.00 meters

$\mathrm{Y}=8.0$ if girth is more than 2 meters

\section{Results and Discussion}

Body measurements and body weights of Red Kandhari bullocks at more than 36 months of age

\section{Body weight}

It is observed from Table 2 that the overall least squares mean for body weight of Red Kandhari bullocks at more than 36 months of age group was $302.92 \pm 1.73 \mathrm{~kg}$. The least squares means of body weight for $\mathrm{D}_{1}, \mathrm{D}_{2}, \mathrm{D}_{3}$, $\mathrm{D}_{4}$, and $\mathrm{D}_{5}$ districts were $289.81 \pm 4.00$, $297.16 \pm 3.45,300.40 \pm 3.07,305.20 \pm 3.68$ and $322.03 \pm 4.94 \mathrm{~kg}$, respectively. The least squares analysis of variance has revealed that highly significant $(\mathrm{P}<0.01)$ effect of districts on body weight of Red Kandhari bullocks at more than 36 months of age. Higher body weight was reported by Kakade (2013) as $436.64 \pm 1.91 \quad \mathrm{~kg}$, Magar (2013) as $382.77 \pm 3.15 \quad \mathrm{~kg}$, Nikam (2013) as $451.08 \pm 3.46 \quad \mathrm{~kg}$, Shinde (2013) as $454.14 \pm 3.37 \mathrm{~kg}$ and Das (2016) as $375.27 \pm$ $5.29 \mathrm{~kg}$ in Red Kandhari bullocks, respectively. Lower body weight was reported by Shikalgar (2011) as $255.55 \pm 3.79 \mathrm{~kg}$ in Khillar bullocks. The overall picture of body weight and body measurements of Red Kandhari bullocks at more than 36 months of 
age may be attributed to the fact that these bullocks are reared in field condition in the breeding tract with almost all unfavourable feeding conditions during the present study as the Marathwada region was reeling under draught conditions resulting into the comparably lower morphometric performance. Hence it is concluded that geoecological situations of surveyed area and management practices followed there plays an important role on physical measurements parameters of Red Kandhari bullocks.

\section{Chest girth}

It is observed from Table 2 that the overall least squares mean for chest girth of Red Kandhari bullocks at more than 36 months of age group was $178.27 \pm 0.46 \mathrm{~cm}$. The least squares means of chest girth for $\mathrm{D}_{1}, \mathrm{D}_{2}, \mathrm{D}_{3}$, $\mathrm{D}_{4}$, and $\mathrm{D}_{5}$ districts were $175.14 \pm 1.07$, $181.81 \pm 0.92,176.10 \pm 0.82,175.48 \pm 0.98$ and $182.80 \pm 1.32 \mathrm{~cm}$, respectively. The least squares analysis of variance has revealed significant $(\mathrm{P}<0.05)$ effect of districts on chest girth of Red Kandhari bullocks at more than 36 of age. Similar findings for chest girth were reported by Nikam (2013) as $179.86 \pm 0.37 \mathrm{~cm}$ in Red Kandhari bullocks. Higher chest girth was reported by Shikalgar (2011) as $185.98 \pm 1.15 \mathrm{~cm}$ in Khillar bullocks and lower chest girth was reported by Pundir and Singh (2008) as $169.70 \pm 1.00$ $\mathrm{cm}$ and Das (2016) as $171.73 \pm 0.77 \mathrm{~cm}$ in Red Kandhari bullocks, respectively.

\section{Body length}

It is observed from Table 2 that the overall least squares mean for body length of Red Kandhari bullocks at more than 36 months of age group was $143.94 \pm 0.51 \mathrm{~cm}$. The least squares means of body length for $\mathrm{D}_{1}, \mathrm{D}_{2}, \mathrm{D}_{3}$, $\mathrm{D}_{4}$, and $\mathrm{D}_{5}$ districts were $141.60 \pm 1.18$, $138.89 \pm 1.02,144.86 \pm 0.91,146.30 \pm 1.09$ and $148.06 \pm 1.46 \mathrm{~cm}$, respectively. The least squares analysis of variance has revealed significant effect of district on body length of Red Kandhari bullocks at more than 36 months of age. Similar findings for body length were reported by Gaikwad et al., (1990) as $141.50 \mathrm{~cm}$ in adult age group of Red Kandhari bullocks. Higher body length was reported by Nikam (2013) as $151.39 \pm 0.96 \mathrm{~cm}$ and lower body length was reported by Pundir and Singh (2008) as $118.20 \pm 1.30 \mathrm{~cm}$ and Das (2016) as 137.44 $\pm 1.00 \mathrm{~cm}$ in Red Kandhari bullocks, respectively.

The lower value for body length than the present investigation, reported by various authors in Red Kandhari bullocks may be based on the study from different areas and management condition pattern followed in that particular area rather than farmers of present study.

\section{Height at wither}

It is observed from Table 2 that the overall least squares mean for height at wither of Red Kandhari bullocks at more than 36 months of age group was $141.24 \pm 0.39 \mathrm{~cm}$. The least squares means of height at wither for $\mathrm{D}_{1}, \mathrm{D}_{2}$, $\mathrm{D}_{3}, \mathrm{D}_{4}$, and $\mathrm{D}_{5}$ districts were $137.88 \pm 0.89$, $144.09 \pm 0.77,141.90 \pm 0.69,140.40 \pm 0.82$ and $141.94 \pm 1.11 \mathrm{~cm}$, respectively. The least squares analysis of variance has revealed that non-significant effect of districts on height at wither of Red Kandhari bullocks at more than 36 months of age. Similar findings for height at wither were reported by Das (2016) as $141.03 \pm 1.11 \mathrm{~cm}$ in Red Kandhari bullocks. Higher height at wither was reported by Nikam (2013) as 152.65+0.49 $\mathrm{cm}$ and lower height at wither was reported than present study by Pundir and Singh (2008) as $131.1 \pm$ $1.00 \mathrm{~cm}$ and Magar (2013) as $134.18 \pm$ $0.37 \mathrm{~cm}$ in Red Kandhari bullocks, respectively. 


\section{Belly girth}

It is observed from Table 2 that the overall least squares mean for belly girth of Red Kandhari bullocks at more than 36 months of age group was $194.07 \pm 0.54 \mathrm{~cm}$. The least squares means of belly girth for $\mathrm{D}_{1}, \mathrm{D}_{2}, \mathrm{D}_{3}$, $\mathrm{D}_{4}$, and $\mathrm{D}_{5}$ districts were $187.92 \pm 1.24$, $195.86 \pm 1.07,195.50 \pm 0.95,190.98 \pm 1.14$ and $200.10 \pm 1.53 \mathrm{~cm}$, respectively. The least squares analysis of variance has revealed that highly significant $(\mathrm{P}<0.01)$ effect of district on the belly girth of Red Kandhari bullocks at more than 36 months of age. Lower belly girth was reported by Singh et al., (2008) as $174.14 \pm 1.92 \mathrm{~cm}$ in Hallikar cattle and Das (2016) as $182.11 \pm 0.83 \mathrm{~cm}$ in Red Kandhari bullocks, respectively. Lower belly girth reported by various authors in indigenous cattle breeds might be due to difference in their genetic makeup coupled with differences in their management and environment to which they are exposed. The present data being the field observations of Red Kandhari cattle bullocks from breeding tract hence the higher belly girth might have been recorded.

\section{Height at hip bone}

It is observed from Table 2 that the overall least squares mean for height at hip bone of Red Kandhari bullocks at more than 36 months of age group was $144.97 \pm 0.39 \mathrm{~cm}$. The least squares means of height at hip bone for $D_{1}, D_{2}, D_{3}, D_{4}$, and $D_{5}$ districts were $142.30 \pm 0.90,147.42 \pm 0.77,145.01 \pm 0.69$, $145.17 \pm 0.83$ and $144.94 \pm 1.11 \mathrm{~cm}$, respectively.

The least squares analysis of variance (Table 3 ) has revealed that non- significant effect of districts on height at hip bone of Red Kandhari bullocks at more than 36 months of age. Similar finding for height at hip bone was reported by Das (2016) as $142.79 \pm 1.08$ $\mathrm{cm}$ in Red Kandhari bullocks.

\section{Length of body at trunk}

It is observed from Table 2 that the overall least squares mean for length of body at trunk of Red Kandhari bullocks at more than 36 months of age group was $111.45 \pm 0.29 \mathrm{~cm}$. The least squares means of Length of body at trunk for $\mathrm{D}_{1}, \mathrm{D}_{2}, \mathrm{D}_{3}, \mathrm{D}_{4}$, and $\mathrm{D}_{5}$ districts were $114.47 \pm 0.67,113.62 \pm 0.57,109.55 \pm 0.51$, $108.76 \pm 0.61$ and $110.87 \pm 0.82 \mathrm{~cm}$, respectively. The least squares analysis of variance has revealed that non-significant effect of districts on length of body at trunk of Red Kandhari bullocks at more than 36 months of age.

\section{Body measurements of Red Kandhari bullocks at more than 36 months age}

\section{Face measurement}

It is observed from Table 3 that the overall least squares mean for face measurement of Red Kandhari bullocks at more than 36 months of age group was $56.36 \pm 0.16 \mathrm{~cm}$. The least squares means of face measurement for $\mathrm{D}_{1}, \mathrm{D}_{2}, \mathrm{D}_{3}, \mathrm{D}_{4}$, and $\mathrm{D}_{5}$ districts were 58.58 $\pm 0.38,55.16 \pm 0.33,55.71 \pm 0.29,55.94 \pm$ 0.35 and $56.42 \pm 0.47 \mathrm{~cm}$, respectively. The least squares analysis of variance has revealed non-significant effect of district on the face measurement of Red Kandhari bullocks at more than 36 months of age. Similar findings for face measurement were reported by Das (2016) as $53.82 \pm 0.36 \mathrm{~cm}$ in Red Kandhari cattle. Higher value was reported by Magar (2013) as $59.32 \pm 0.16$ and lower value was reported by Pundir and Singh (2008) as 48.6 $\pm 0.30 \mathrm{~cm}$ in Red Kandhari cattle, respectively.

\section{Tail length}

It is observed from Table 3 that the overall least squares mean for tail length of Red Kandhari bullocks at more than 36 months of 
age group was $99.06 \pm 0.20 \mathrm{~cm}$. The least squares means of tail length for $\mathrm{D}_{1}, \mathrm{D}_{2}, \mathrm{D}_{3}$, $\mathrm{D}_{4}$, and $\mathrm{D}_{5}$ districts were $100.99 \pm 0.47$, $102.65 \pm 0.40,96.97 \pm 0.36,97.55 \pm 0.43$ and $97.15 \pm 0.58 \mathrm{~cm}$, respectively. The least squares analysis of variance has revealed nonsignificant effect of district on tail length of Red Kandhari bullocks at more than 36 months of age. Higher value was reported by Singh et al., (2008) as $108.78 \pm 1.21 \mathrm{~cm}$ in Hallikar cattle and lower was reported by Magar (2013) as $95.27 \pm 0.21 \mathrm{~cm}$, Pundir and Singh (2008) as $85.3 \pm 0.90 \mathrm{~cm}$ in Red Kandhari Bullocks, respectively.

\section{Ear length}

It is observed from Table 3 that the overall least squares mean for ear length of Red Kandhari bullocks at more than 36 months of age group was $26.09 \pm 0.10 \mathrm{~cm}$. The least squares means of ear length for $\mathrm{D}_{1}, \mathrm{D}_{2}, \mathrm{D}_{3}$, $\mathrm{D}_{4}$, and $\mathrm{D}_{5}$ districts were $25.79 \pm 0.23,26.58$ $\pm 0.19,25.92 \pm 0.17,26.11 \pm 0.21$ and 26.05 $\pm 0.28 \mathrm{~cm}$, respectively. The least squares analysis of variance has revealed nonsignificant effect of district on ear length of
Red Kandhari bullocks at more than 36 months of age. The similar findings for face measurement were reported by Magar (2013) as $25.82 \pm 0.09 \mathrm{~cm}$ and Das (2016) as $27.11 \pm$ $0.24 \mathrm{~cm}$ in Red Kandhari bullocks, respectively. Lower value was reported by Pundir and Singh (2008) as $23.9 \pm 0.4 \mathrm{~cm}$ in Red Kandhari bullocks.

\section{Horn length}

It is observed from Table 3 that the overall Least Squares mean for horn length of Red Kandhari bullocks at more than 36 months of age group was $16.02 \pm 0.24 \mathrm{~cm}$. The Least Squares means of horn length for $D_{1}, D_{2}, D_{3}$, $\mathrm{D}_{4}$, and $\mathrm{D}_{5}$ districts were $13.56 \pm 0.55,13.70$ $\pm 0.47,14.59 \pm 0.42,19.50 \pm 0.50$ and 18.76 $\pm 0.68 \mathrm{~cm}$, respectively. The least squares analysis of variance has revealed nonsignificant effect of district on horn length of Red Kandhari bullocks at more than 36 months of age. Higher value was reported by Pundir and Singh (2008) as $21.0 \pm 0.50 \mathrm{~cm}$, Magar (2013) as $21.24 \pm 0.31 \mathrm{~cm}$ and Das (2016) as $18.75 \pm 0.62 \mathrm{~cm}$ in Red Kandhari bullocks, respectively.

Table.1 List of villages randomly selected for collection of data

\begin{tabular}{|c|c|c|c|}
\hline Sr. No. & $\begin{array}{l}\text { Name of the } \\
\text { District }\end{array}$ & $\begin{array}{l}\text { Name of the } \\
\text { Tehsils }\end{array}$ & Name of the Villages \\
\hline \multirow[t]{2}{*}{1.} & \multirow[t]{2}{*}{ Nanded $\left(\mathrm{D}_{1}\right)$} & Kandhar & $\begin{array}{l}\text { Bori (Khu.), Umaraj, Jambhulwadi, Dagadsangavi, } \\
\text { Ghodaj }\end{array}$ \\
\hline & & Loha & $\begin{array}{c}\text { Dhanora (Makta), Subhashnagar, Chitali, Malakoli, } \\
\text { Malegaon }\end{array}$ \\
\hline \multirow[t]{2}{*}{2.} & \multirow[t]{2}{*}{ Latur $\left(D_{2}\right)$} & Ahmedpur & $\begin{array}{c}\text { Sangavi (Su.), Sunegaon (Sa.), Babaldara, Hippalgaon, } \\
\text { Sawargaon (Thot) }\end{array}$ \\
\hline & & Jalkot & Kunki, Wanjarwada, Hawarga, Jirga, Jagalpur \\
\hline \multirow[t]{2}{*}{3.} & \multirow[t]{2}{*}{ Parbhani $\left(\mathrm{D}_{3}\right)$} & Palam & Kerwadi, Shirpur, Sayal, Kapsi, Pethshivani \\
\hline & & Gangakhed & $\begin{array}{c}\text { Dhavalkewadi, Kaudgaon, Malewadi, Maradasgaon, } \\
\text { Naralad }\end{array}$ \\
\hline \multirow[t]{2}{*}{4.} & \multirow[t]{2}{*}{ Hingoli $\left(D_{4}\right)$} & Vasmat & Aaral, Darephal, Bori, Aadgaon, Kalamba \\
\hline & & Aundha & Barashiv, Ranjala, Purjal, Sirla, Aajarsonda \\
\hline 5. & Beed $\left(D_{5}\right)$ & Parli & Tokwadi, Sangam, Waghbet, Belamba, Injegaon \\
\hline
\end{tabular}


Table.2 LSM and SE for body measurements $(\mathrm{cm})$ and body weights $(\mathrm{kg})$ of Red Kandhari bullocks at more than 36 months age

\begin{tabular}{|c|c|c|c|c|c|c|c|c|c|}
\hline \multirow[t]{2}{*}{ Sources } & \multirow[t]{2}{*}{ Code } & \multirow[t]{2}{*}{$\mathbf{N}$} & \multicolumn{7}{|c|}{$\mathrm{LSM} \pm \mathrm{SE}$} \\
\hline & & & $\begin{array}{l}\text { Body weight } \\
(\mathrm{kg})\end{array}$ & $\begin{array}{l}\text { Chest girth } \\
\text { (cm) }\end{array}$ & $\begin{array}{l}\text { Body length } \\
\text { (cm) }\end{array}$ & $\begin{array}{l}\text { Height at } \\
\text { wither }(\mathrm{cm})\end{array}$ & Belly girth $(\mathrm{cm})$ & $\begin{array}{l}\text { Height at } \\
\text { hip bone } \\
\text { (cm) }\end{array}$ & $\begin{array}{l}\text { Length of } \\
\text { body at } \\
\text { trunk }(\mathrm{cm})\end{array}$ \\
\hline $\begin{array}{l}\text { Population } \\
\text { mean }\end{array}$ & $\mu$ & 851 & $302.92 \pm 1.73$ & $178.27 \pm 0.46$ & $143.94 \pm 0.51$ & $141.24 \pm 0.39$ & $194.07 \pm 0.54$ & $144.97 \pm 0.39$ & $111.45 \pm 0.29$ \\
\hline \multicolumn{10}{|l|}{ District } \\
\hline Nanded & $\mathrm{D}_{1}$ & 145 & $289.81^{\mathrm{a}} \pm 4.00$ & $175.14^{\mathrm{a}} \pm 1.07$ & $141.60^{\mathrm{a}} \pm 1.18$ & $137.88 \pm 0.89$ & $187.92^{\mathrm{a}} \pm 1.24$ & $142.30 \pm 0.90$ & $114.47 \pm 0.67$ \\
\hline Latur & $\mathrm{D}_{2}$ & 195 & $297.16^{\mathrm{a}} \pm 3.45$ & $181.81^{\mathrm{b}} \pm 0.92$ & $138.89^{\mathrm{a}} \pm 1.02$ & $144.09 \pm 0.77$ & $195.86^{\mathrm{b}} \pm 1.07$ & $147.42 \pm 0.77$ & $113.62 \pm 0.57$ \\
\hline Parbhani & $\mathrm{D}_{3}$ & 245 & $300.40^{\mathrm{b}} \pm 3.07$ & $176.10^{\mathrm{a}} \pm 0.82$ & $144.86^{\mathrm{b}} \pm 0.91$ & $141.90 \pm 0.69$ & $195.50^{\mathrm{b}} \pm 0.95$ & $145.01 \pm 0.69$ & $109.55 \pm 0.51$ \\
\hline Hingoli & $\mathrm{D}_{4}$ & 171 & $305.20^{\mathrm{b}} \pm 3.68$ & $175.48^{\mathrm{a}} \pm 0.98$ & $146.30^{\mathrm{b}} \pm 1.09$ & $140.40 \pm 0.82$ & $190.98^{\mathrm{a}} \pm 1.14$ & $145.17 \pm 0.83$ & $108.76 \pm 0.61$ \\
\hline Beed & $\mathrm{D}_{5}$ & 95 & $322.03^{\mathrm{bc}} \pm 4.94$ & $182.80^{\mathrm{b}} \pm 1.32$ & $148.06^{\mathrm{b}} \pm 1.46$ & $141.94 \pm 1.11$ & $200.10^{b c} \pm 1.53$ & $144.94 \pm 1.11$ & $110.87 \pm 0.82$ \\
\hline
\end{tabular}

Note: Means connected by same superscripts do not differ significantly

Table.3 LSM and SE for body measurements (cm) of Red Kandhari bullocks at more than 36 months age

\begin{tabular}{|c|c|c|c|c|c|c|c|c|}
\hline \multirow[t]{2}{*}{ Sources } & \multirow[t]{2}{*}{ Code } & \multirow[t]{2}{*}{$\mathbf{N}$} & \multicolumn{6}{|l|}{$\mathrm{LSM} \pm \mathrm{SE}$} \\
\hline & & & $\begin{array}{l}\text { Face } \\
\text { measurement } \\
(\mathrm{cm})\end{array}$ & $\begin{array}{l}\text { Tail length } \\
(\mathrm{cm})\end{array}$ & $\begin{array}{l}\text { Ear length } \\
(\mathrm{cm})\end{array}$ & $\begin{array}{l}\text { Horn } \\
\text { length }(\mathrm{cm})\end{array}$ & $\begin{array}{l}\text { Fore legs } \\
\text { length }(\mathrm{cm})\end{array}$ & $\begin{array}{l}\text { Hind legs } \\
\text { length } \\
(\mathrm{cm})\end{array}$ \\
\hline Population mean & $\mu$ & 851 & $56.36 \pm 0.16$ & $99.06 \pm 0.20$ & $26.09 \pm 0.10$ & $16.02 \pm 0.24$ & $97.18 \pm 0.16$ & $55.72 \pm 0.10$ \\
\hline \multicolumn{9}{|l|}{ District } \\
\hline Nanded & $\mathrm{D}_{1}$ & 145 & $58.58 \pm 0.38$ & $100.99 \pm 0.47$ & $25.79 \pm 0.23$ & $13.56 \pm 0.55$ & $95.89 \pm 0.37$ & $57.00 \pm 0.24$ \\
\hline Latur & $\mathrm{D}_{2}$ & 195 & $55.16 \pm 0.33$ & $102.65 \pm 0.40$ & $26.58 \pm 0.19$ & $13.70 \pm 0.47$ & $99.29 \pm 0.32$ & $56.66 \pm 0.20$ \\
\hline Parbhani & $\mathrm{D}_{3}$ & 245 & $55.71 \pm 0.29$ & $96.97 \pm 0.36$ & $25.92 \pm 0.17$ & $14.59 \pm 0.42$ & $97.06 \pm 0.28$ & $54.74 \pm 0.18$ \\
\hline Hingoli & $\mathrm{D}_{4}$ & 171 & $55.94 \pm 0.35$ & $97.55 \pm 0.43$ & $26.11 \pm 0.21$ & $19.50 \pm 0.50$ & $96.15 \pm 0.34$ & $55.12 \pm 0.22$ \\
\hline Beed & $\mathrm{D}_{5}$ & 95 & $56.42 \pm 0.47$ & $97.15 \pm 0.58$ & $26.05 \pm 0.28$ & $18.76 \pm 0.68$ & $97.49 \pm 0.45$ & $55.10 \pm 0.29$ \\
\hline
\end{tabular}




\section{Fore legs length}

It is observed from Table 3 that the overall least squares mean for fore legs length of Red Kandhari bullocks at more than 36 months of age group was $97.18 \pm 0.16 \mathrm{~cm}$. The least squares means of fore legs length for $\mathrm{D}_{1}, \mathrm{D}_{2}$, $\mathrm{D}_{3}, \mathrm{D}_{4}$, and $\mathrm{D}_{5}$ districts were $95.89 \pm 0.37$, $99.29 \pm 0.32,97.06 \pm 0.28,96.15 \pm 0.34$ and $97.49 \pm 0.45 \mathrm{~cm}$, respectively. The least squares analysis of variance has revealed nonsignificant effect of district on fore legs length of Red Kandhari bullocks at more than 36 months of age.

\section{Hind legs length}

It is observed from Table 3 that the overall least squares mean for hind legs length of Red Kandhari bullocks at more than 36 months of age group was $55.72 \pm 0.10 \mathrm{~cm}$. The least squares means of hind legs length for $\mathrm{D}_{1}, \mathrm{D}_{2}$, $\mathrm{D}_{3}, \mathrm{D}_{4}$, and $\mathrm{D}_{5}$ districts were $57.00 \pm 0.24$, $56.66 \pm 0.20,54.74 \pm 0.18,55.12 \pm 0.22$ and $55.10 \pm 0.29 \mathrm{~cm}$, respectively. The least squares analysis of variance has revealed nonsignificant effect of district on hind legs length of Red Kandhari bullocks at more than 36 months of age.

In conclusion the effect of block was found significant to highly significant on body weight of Red Kandhari bullocks at more than 36 months of age group. The effect of block was found significant to highly significant on chest girth, body length and belly girth in > 36 month male group of animals. Hence it is concluded that geo-ecological situations of surveyed area and management practices followed there plays an important role on physical measurements parameters of Red Kandhari bullocks.

\section{Acknowledgment}

I have immense pleasure in expressing my whole hearted sense of gratitude indebtedness towards my Research Guide respected Dr. B. M. Thombre, Associate Dean and Principal, College of Agriculture, Ambajogai, Vasantrao Naik Marathwada Krishi Vidyapeeth, Parbhani, who in the unique way, provided me with constant encouragement, inspiring, scholastic guidance and above all, friendly advice, love and affection offered to me during the course of my study and research.

\section{References}

Chauhan, D.S., Thombre, B.M., Mitkari, K.R., Yadav, K.N. and Bainwad, D.V. 2008. Origin and Historical Background of Red Kandhari Cattle of Maharashtra. National Symposium - SOCDAB, Veterinary College, Bangalore: 266.

Das S. 2016. Morphometric Characterization of Red Kandhari Cattle in Their Breeding Tract. M.V. Sc. Thesis submitted to MAFSU, Nagpur (MS).

Gaikwad, B.B., Sakhare, P.G. and Deshpande, K.J. 1990. A note on Body Measurements of Red Kandhari Breed, of Cattle. Indian Vet. J., 67 (12): 1172.

Harvey, W.R. 1990. Least Squares Analysis of Data with Unequal Subclass Numbers, Agricultural Research Service, United State, Department of Agriculture, Washington, D.C. Kakade P.A. 2013. Studies on Morphometric Characteristics of Red Kandhari Cattle in Latur District. M. Sc. (Agri.) Thesis Submitted to MAU, Parbhani (MS).

Magar S.V. 2013. Studies on Morphometric Characteristics of Red Kandhari Cattle in Hingoli District. M. Sc. (Agri.) Thesis Submitted to MAU, Parbhani (MS). NBAGR, 2017. Registered breeds of livestock. www.nbagr.res.in Nikam M.S. 2013. Studies on Morphometric Characteristics of Red Kandhari Cattle in Parbhani District. M. Sc. (Agri.) Thesis Submitted to MAU, 
Parbhani (MS).

Patoo R.A., D.V. Singh, S.K. Singh, B.K. Chaudhari, A.K. Singh1, M.K. Singh and S. Kaushal, 2016. Comparative study on some morphological and performance traits of Hill cattle, Sahiwal and crossbred cattle. Indian J. Anim. Res., 50(2): 148-151.

Pundir R.K. and P.K. Singh, 2008. Status, Characteristics and Performance of Red Kandhari Cattle Breed in its Native Tract. Indian J. Anim. Sci. 78 (1): 5661.

Shikalgar N.S. 2011. Phenotypic Characterization of Khillar Cattle at
Organized Farm. M.Sc. Thesis submitted to MAU, Parbhani, (MS), India.

Shinde Y. P. 2013. Studied on Morphometric characteristics of Red Kandhari Cattle in Nanded District. M. Sc. (Agri) Thesis Submitted to MAU, Parbhani (MS).

Singh P. K., R. K. Pundir, S. P. S. Ahlawat, S. Naveen Kumar, M. G. Govindaiah and Karuna

Asija, 2008. Phenotypic characterization and performance evaluation of Hallikar cattle in its native tract. Indian Journal of Animal Sciences, 78 (2): 211-214.

\section{How to cite this article:}

Bainwad, D. V., B. M. Thombre and Londhe, G. K. 2020. Studies on Linear Body Measurements of Red Kandhari Bullocks in Their Breeding Tract of Maharashtra. Int.J.Curr.Microbiol.App.Sci. 9(09): 62-69. doi: https://doi.org/10.20546/ijcmas.2020.909.007 